\title{
Activation of Pozzolanic and Latent-Hydraulic Reactions by Alkalis in Order to Repair Concrete Cracks
}

\author{
Elke Gruyaert, Ph.D. ${ }^{1}$; Kim Van Tittelboom, Ph.D. ${ }^{2}$; Hubert Rahier, Ph.D. ${ }^{3}$; and Nele De Belie, Ph.D. ${ }^{4}$
}

\begin{abstract}
The low degree of hydration of fly ash (FA) and slag (BFS) particles in high-volume FA and BFS concrete offers the possibility to activate the unreacted particles upon crack formation to close the crack. In this paper, a preliminary study is performed to evaluate the use of alkaline activators to stimulate the formation of reaction products in the crack. First, the reaction rates of crushed pastes mixed with alkaline solutions or water were monitored by calorimetry. These tests showed that alkaline activators stimulate the reactions more than water. Secondly, cracked mortar beams were stored in different alkaline solutions or water and the crack self-closing ratio was calculated after microscopic investigation at different time intervals. The results indicated that reference mixes, containing only ordinary portland cement as binder, heal very well autogenously, while a solution of $\mathrm{Ca}(\mathrm{OH})_{2}+\mathrm{Na}_{2} \mathrm{CO}_{3}$ seems to be the most suitable activator to stimulate crack closing of BFS concrete. Thirdly, the regain in strength due to healing of the cracks was determined. Compared to other self-healing techniques, strength regain is limited (about 10-40\%). DOI: 10.1061/(ASCE)MT.1943-5533.0001162. @ 2014 American Society of Civil Engineers.
\end{abstract}

Author keywords: Blast-furnace slag; Fly ash; Alkaline activation; Self-healing.

\section{Introduction}

Just like biological materials, concrete exhibits to a certain extent self-healing properties. Due to hydration of unreacted cement grains or precipitation of calcium carbonate particles, small cracks in concrete can be repaired. This natural self-healing process is called autogenous crack healing. However, the efficiency of this process is limited as it is only active when water is available and as it is limited to the repair of small cracks $[<200 \mu \mathrm{m}$ (Van Tittelboom et al. 2012b)]. Recently, many studies are devoted to the improvement of the self-healing capacity of concrete by the addition of engineered components (other than the normal concrete components), named autonomous crack healing. Within this research area, different mechanisms are under development. The most common ones use encapsulated polymers (Dry and McMillan 1996; Thao et al. 2009; Van Tittelboom et al. 2011), calcium carbonate precipitating bacteria (Wiktor and Jonkers 2011;

\footnotetext{
${ }^{1}$ Magnel Laboratory for Concrete Research, Dept. of Structural Engineering, Faculty of Engineering and Architecture, Ghent Univ., Technologiepark-Zwijnaarde 904, 9052 Ghent, Belgium; and SIM vzw, Technologiepark-Zwijnaarde 935, 9052 Ghent, Belgium. E-mail: Elke .Gruyaert@UGent.be

${ }^{2}$ Magnel Laboratory for Concrete Research, Dept. of Structural Engineering, Faculty of Engineering and Architecture, Ghent Univ., Technologiepark-Zwijnaarde 904, 9052 Ghent, Belgium. E-mail: kim .vantittelboom@ugent.be

${ }^{3}$ Professor, FYSC, Dept. Materials and Chemistry, Faculty of Engineering, Vrije Universiteit Brussel, Pleinlaan 2, 1050 Brussels, Belgium. E-mail: hrahier@vub.ac.be

${ }^{4}$ Professor, Magnel Laboratory for Concrete Research, Dept. of Structural Engineering, Faculty of Engineering and Architecture, Ghent Univ., Technologiepark-Zwijnaarde 904, 9052 Ghent, Belgium (corresponding author). E-mail: nele.debelie@ugent.be

Note. This manuscript was submitted on January 14, 2014; approved on July 16, 2014; published online on September 9, 2014. Discussion period open until February 9, 2015; separate discussions must be submitted for individual papers. This paper is part of the Journal of Materials in Civil Engineering, (C) ASCE, ISSN 0899-1561/04014208(12)/ $\$ 25.00$.
}

Van Tittelboom et al. 2010; Wang et al. 2012), or embedded hydrogels (Dennis Lee et al. 2010; Kim and Schlangen 2010; Snoeck et al. 2013) as healing/sealing agents. The current paper describes a preliminary study to evaluate whether alkaline activators can be used as healing agents in order to obtain self-healing in special types of concrete such as those containing large amounts of unhydrated fly ash (FA) or blast-furnace slag (BFS) particles.

Many researchers (e.g., Deschner et al. 2013; Kocaba et al. 2012; Lumley et al. 1996; Gruyaert et al. 2010; Gruyaert 2011; Baert 2009) determined the degree of reaction of FA/BFS. Baert (2009) showed that the degree of pozzolanic reaction in a cement paste with 50\% FA and 50\% ordinary portland cement (OPC) and a water-to-binder ratio of 0.4 was only a few percent after 28 days and $20 \%$ after 180 days (selective dissolution-picric acid). Gruyaert et al. (2010) found that the degree of reaction of BFS was about $37 \%$ after 28 days curing in water and about $70 \%$ after 2.5 years curing in water for mixes containing 50\% OPC and 50\% $\mathrm{BFS}$ and a water-to-binder ratio of 0.5 (BSE image analysis). In the case of higher replacement percentages, the slag reactivity decreased significantly and a degree of reaction of only $39 \%$ was reached for pastes with a slag-to-binder ratio of $85 \%$ after 2.5 years. With regard to self-healing, this means that the particles that have not yet reacted can still be activated upon crack formation and form reaction products that close the crack. In the current research project, the possibility to stimulate these reactions by using alkaline activators is investigated. Encapsulated activators are embedded in the concrete mix. At the moment of crack appearance, the capsules break and the activator is released into the crack. Upon contact of the activator with the unhydrated FA or BFS particles, new hydration products are formed, which fill up the crack and result in crack repair. This idea was based on the principle of alkali-activated cements and concretes, where cementing components like fly ash or slag are mixed with, e.g., caustic alkalis or alkaline salts in order to activate the pozzolanic or slag reaction (Shi et al. 2006). During alkaline activation, aluminosilicates are attacked by the high alkaline solution and small (alumino)silicate anions go into solution. These anions recombine via a condensation mechanism 
( $\mathrm{H}_{2} \mathrm{O}$ is split off) to form a new aluminosilicate network. It is commonly known that pure FA and BFS can be alkali-activated.

The first research on and use of alkali-activated cements dates from the first half of the 20th century [A. O. Purdon, "Improvements in processes of manufacturing cement, mortars, and concretes," Great Britain Patent No. GB427227A (1935); Purdon 1940; Shi et al. 2006; Buchwald et al. 2013] and the properties of concrete made with alkali-activated binders (e.g., low $\mathrm{CO}_{2}$ emission during production, high strength at early ages, high resistance to aggressive environments) make them still scientifically and commercially interesting (Shi et al. 2006; Bernal et al. 2011). In the past, much research has been performed in order to select the most suitable activators and to determine the effect of these activators on early-age and late-age properties (e.g., setting time, strength, shrinkage). Many parameters like reactivity of the binder and type, concentration, and dosage of the activator play an important role, but in general, the following could be found in the literature:

1. Alkali-hydroxides like $\mathrm{NaOH}, \mathrm{KOH}$, and $\mathrm{Ca}(\mathrm{OH})_{2}$ are able to react with $\mathrm{SiO}_{2}$ and $\mathrm{Al}_{2} \mathrm{O}_{3}$ to produce hydrated calcium silicate and calcium aluminate phases. They can break the Si-O, Al-O bonds in the vitreous body of the fly ash and accelerate dissolution of $\mathrm{Si}_{4}^{+}$and $\mathrm{Al}_{3}^{+}$(Arjunan et al. 2001; as cited by Baert 2009).

2. According to Shi et al. (2006), the most commonly used activators are $\mathrm{NaOH}, \mathrm{Na}_{2} \mathrm{CO}_{3}, \mathrm{Na}_{2} \mathrm{O} \cdot \mathrm{nSiO}_{2}$, and $\mathrm{Na}_{2} \mathrm{SO}_{4}$. These products are widely available and relatively cheap. Potassium compounds yield similar properties, but are costly and their availability is more limited.

3. Purdon (Great Britain Patent No. GB427227A) reported that caustic alkalis like $\mathrm{NaOH}$ or $\mathrm{KOH}$ can activate the blastfurnace slag reaction. These caustic alkalis can be added directly to the cement or $\mathrm{NaOH}$ can be formed at the moment of cement wetting by adding, e.g., $\mathrm{Na}_{2} \mathrm{CO}_{3}$ (or $\mathrm{Na}_{2} \mathrm{SO}_{4}$ ) and $\mathrm{Ca}(\mathrm{OH})_{2}$ (Purdon 1940).

4. The state-of-the-art report of RILEM TC-224 AAM (Provis and van Deventer 2014) gives a summary of the different combinations of solid precursors and alkaline activators that have been shown to be feasible and/or desirable. For BFS, $\mathrm{M}_{2} \mathrm{O} \cdot \mathrm{rSiO}_{2}$ is classified as desirable, $\mathrm{M}_{2} \mathrm{CO}_{3}$ as good, and $\mathrm{MOH}$ and $\mathrm{M}_{2} \mathrm{SO}_{4}$ as acceptable. For FA, $\mathrm{MOH}$, and $\mathrm{M}_{2} \mathrm{O} \cdot \mathrm{rSiO}_{2}$ are classified as desirable, $\mathrm{NaAlO}_{2}$ as acceptable, and $\mathrm{M}_{2} \mathrm{CO}_{3}$ as poor (or acceptable with cement/clinker addition). The combination of FA with $\mathrm{M}_{2} \mathrm{SO}_{4}$ can only be used with cement/clinker addition.

Most of the mentioned activators were used in the current research. Moreover, in order to quantify the (beneficial) effect of alkaline activation on crack repair, also the autogenous healing capability was determined. A paper on autogenous healing in cementitious materials with alternative binders has been published (Van Tittelboom et al. 2012b) and we refer to it for more information.

\section{Materials and Methods}

\section{Cement Pastes and Mortars}

In order to make the cement pastes and mortars, cement CEM I 52.5 N, complying with the Standard NBN EN 197-1 (NBN 2011), was used and FA or BFS was added to the mixtures as a separate component. The characteristics of the cement, FA, and BFS are summarized in Table 1. For some of the mixtures, also PVA fibers and superplasticizer were used. The PVA fibers (Kuraray, Tokyo, Japan) had a length of $8 \mathrm{~mm}$ and were coated with $1.2 \%$ oil. The superplasticizer was Glenium 51 (BASF, Oosterhout, Netherlands).
Table 1. Chemical Composition (\%), Blaine Fineness $\left(\mathrm{m}^{2} / \mathrm{kg}\right)$, and Density $\left(\mathrm{kg} / \mathrm{m}^{3}\right)$ of Portland Cement CEM I $52.5 \mathrm{~N}$ (OPC), Fly Ash (FA), and Blast-Furnace Slag (BFS)

\begin{tabular}{lccc}
\hline Oxide & \multicolumn{1}{c}{ OPC } & \multicolumn{1}{c}{ FA } & BFS \\
\hline $\mathrm{CaO}$ & 62.04 & 7.58 & 42.64 \\
$\mathrm{SiO}_{2}$ & 18.99 & 50.83 & 33.86 \\
$\mathrm{Al}_{2} \mathrm{O}_{3}$ & 5.97 & 20.45 & 8.91 \\
$\mathrm{Fe}_{2} \mathrm{O}_{3}$ & 4.23 & 7.25 & 0.69 \\
$\mathrm{MgO}$ & 0.96 & 1.77 & 7.39 \\
$\mathrm{~K}_{2} \mathrm{O}$ & 0.66 & 1.69 & 0.52 \\
$\mathrm{Na}_{2} \mathrm{O}$ & 0.46 & 1.00 & 0.28 \\
$\mathrm{SO}_{3}$ & 3.18 & 0.68 & 1.62 \\
$\mathrm{CO}_{2}$ & 0.88 & - & 0.36 \\
Density & 3,062 & 2,260 & 2,936 \\
Blaine fineness & 383 & 288 & 397 \\
\hline
\end{tabular}

\section{Alkaline Activators}

Based on the literature review, the most suitable activators were selected (Table 2) for each type of binder composition. For comparison, also the autogenous healing efficiency of our mixtures was determined by replacing the activators with water.

\section{Calorimetry}

To investigate whether FA and BFS particles in cement paste can be reactivated by alkalis after a certain curing period and to investigate the reaction kinetics, crushed cement paste was mixed with an alkaline activator and the hydration heat was registered by an isothermal calorimeter.

\section{Sample Preparation}

Cement pastes with a water-to-binder ratio of 0.4 were mixed with a mortar mixer, similar to the one described in NBN EN 196-1 (NBN 2005). Besides the reference mixes [REF(cp)] containing only OPC as binder (B), pastes containing high amounts of FA (FA/B $=0.3[\mathrm{FA} 30(\mathrm{cp})]$ and $\mathrm{FA} / \mathrm{B}=0.5[\mathrm{FA} 50(\mathrm{cp})])$ or BFS $(\mathrm{BFS} / \mathrm{B}=0.5[\mathrm{~S} 50(\mathrm{cp})]$ and $\mathrm{BFS} / \mathrm{B}=0.85[\mathrm{~S} 85(\mathrm{cp})])$ were made (Table 3$)$. The cast specimens $\left(10 \times 40 \times 160 \mathrm{~mm}^{3}\right)$ were demoulded after $24 \mathrm{~h}$ and cured at $20^{\circ} \mathrm{C}$ and $>95 \% \mathrm{RH}$ until the time of testing. After a minimum of 28 days, a piece of cement paste was broken off, crushed to powder, and sieved on a 200- $\mu \mathrm{m}$ sieve.

\section{Measurement}

Sample ampoules with a maximum content of $4 \mathrm{~mL}$ were filled with $2 \mathrm{~g}$ of crushed paste and $2 \mathrm{~g}$ of activator. After manual mixing of the components, the ampoules were placed in a TAM III $\mu$-calorimeter (TA Instruments Benelux, Zellik, Belgium) to investigate the reaction kinetics between the cement paste powder and the activator at $20^{\circ} \mathrm{C}$. The heat production rate was registered for $\sim 7$ days and the start of the reaction was taken to occur at the end of mixing. In most cases, two replicates were performed (high reproducibility). For clarity, only one curve for each combination will be presented in the Results section.

\section{Microscopy}

The crack closure in mortar specimens submerged in alkaline solutions was monitored by microscopic investigation. The cracks were created by three-point or four-point bending tests. 
Table 2. Tested Combinations of Different Cement Paste Compositions and Activators

\begin{tabular}{|c|c|c|c|c|c|}
\hline Activator & REF & FA30 & FA50 & S50 & S85 \\
\hline Water & C-M 3P-M 4P & C-M 3P-M 4P & C-M 3P-M 4P & C-M 3P-M 4P & C-M 3P-M 4P \\
\hline $\mathrm{NaOH}(1.75 \mathrm{M})$ & C-M 3P-M 4P & - & - & C-M 3P-M 4P & C-M 3P-M 4P \\
\hline $\mathrm{NaOH}(8 \mathrm{M})$ & C-M 3P-M 4P & C-M 3P-M 4P & C-M 3P-M 4P & C-M 4P & C-M 4P \\
\hline $\mathrm{Ca}(\mathrm{OH})_{2}(0.05 \mathrm{M})$ & - & C-M 4P & C-M 4P & - & - \\
\hline $\mathrm{Ca}(\mathrm{OH})_{2}(1.25 \mathrm{M})+\mathrm{Na}_{2} \mathrm{CO}_{3}(1.25 \mathrm{M})^{\mathrm{a}}$ & C-M 4P & C-M 4P & C-M 4P & C-M 3P-M 4P & C-M 3P-M 4P \\
\hline $\mathrm{KOH}(1.96 \mathrm{M})$ & C-M 3P-M 4P & - & - & C-M 3P-M 4P & C-M 3P-M 4P \\
\hline $\mathrm{Na}_{2} \mathrm{O} \cdot 1.5 \mathrm{SiO}_{2} \cdot 13 \mathrm{H}_{2} \mathrm{O}$ & C-M 4P & C-M 4P & C-M 4P & C-M 4P & C-M 4P \\
\hline
\end{tabular}

Note: $\mathrm{C}=$ calorimetry; $\mathrm{M} 3 \mathrm{P}=$ microscopic investigation of crack closure after three-point bending tests; $\mathrm{M} 4 \mathrm{P}=$ microscopic investigation of crack closure after four-point bending tests.

${ }^{\mathrm{a}} 92.5 \mathrm{~g} \mathrm{Ca}(\mathrm{OH})_{2}+132.5 \mathrm{~g} \mathrm{Na}_{2} \mathrm{CO}_{3}+1 \mathrm{~L}$ water; in the case of the $\mathrm{Ca}(\mathrm{OH})_{2} / \mathrm{Na}_{2} \mathrm{CO}_{3}$ activator, the dry components were added to the cement powder before addition of water.

Table 3. Mixture Proportions per Batch Cement Paste (g/batch)

\begin{tabular}{lccccc}
\hline Component & REF(cp) & FA30(cp) & FA50(cp) & S50(cp) & S85(cp) \\
\hline OPC & 450.0 & 315.0 & 225.0 & 225.0 & 67.5 \\
BFS & - & - & - & 225.0 & 382.5 \\
FA & - & 135.0 & 225.0 & - & - \\
Water & 180.0 & 180.0 & 180.0 & 180.0 & 180.0 \\
\hline
\end{tabular}

\section{Three-Point Bending Tests in Order to Create a Single (S) Controlled Crack}

\section{Sample Preparation}

Mortar mixtures, consisting of 1,350 g CEN standard sand, $450 \mathrm{~g}$ binder, and $225 \mathrm{~g}$ water were made according to the procedure described in the standard NBN EN 196-1 (Table 4). The binder consisted of OPC [REF(s)], FA and OPC [FA30(s) and FA50(s)], or BFS and OPC [S50(s) and S85(s)]. For each test series, three mortar prisms $\left(40 \times 40 \times 160 \mathrm{~mm}^{3}\right)$ containing two steel reinforcement bars of diameter $2 \mathrm{~mm}$ were produced and stored in a climate room at $20^{\circ} \mathrm{C}$ and more than $95 \% \mathrm{RH}$. The prisms were demoulded after 1 day and cured for 27 days at $20^{\circ} \mathrm{C}$ and more than 95\% RH.

At the age of 28 days, crack width controlled three-point bending tests were performed in order to obtain a single crack at the middle of the specimen. A linear variable differential transformer (LVDT, range of $\pm 500 \mu \mathrm{m}$ and accuracy of $1 \mu \mathrm{m}$ ), which was attached at the bottom side of the specimen, registered the crack width, which increased at a speed of $0.3 \mu \mathrm{m} / \mathrm{s}$. When the crack width reached $200 \mu \mathrm{m}$, the specimen was unloaded and the crack partly closed. The resulting crack width was measured (at $\sim 9$ locations per crack) with a crack microscope and the maximum values amounted to $100-150 \mu \mathrm{m}$.

\section{Measurement}

The cracked specimens were immersed in different alkaline solutions/water and the crack closure was monitored by microscopic analysis during 6 weeks. After a submersion time of

Table 4. Mortar Composition of REF(s), FA30(s), FA50(s), S50(s), and $\mathrm{S} 85$ (s) (g/batch) (with $\mathrm{s}=$ Single Crack)

\begin{tabular}{lccccr}
\hline Component & REF(s) & FA30(s) & FA50(s) & S50(s) & S85(s) \\
\hline OPC & 450.0 & 315.0 & 225.0 & 225.0 & 67.5 \\
BFS & - & - & - & 225.0 & 382.5 \\
FA & - & 135.0 & 225.0 & - & - \\
Water & 225.0 & 225.0 & 225.0 & 225.0 & 225.0 \\
Sand & $1,350.0$ & $1,350.0$ & $1,350.0$ & $1,350.0$ & $1,350.0$ \\
\hline
\end{tabular}

1 day, 3 (4 or 5), 7, 14, 21, and 42 days, specimens were removed from the solutions. Before microscopic investigation, specimens were wiped with a paper towel and exposed to the air for some time to allow them to dry. Then, crack widths were measured at the same locations as before.

\section{Four-Point Bending Tests in Order to Create Multiple (M) Cracks}

To evaluate the behavior of cracks with different widths upon exposure to alkaline solutions, four-point bending tests were performed on fiber-reinforced mortar samples.

\section{Sample Preparation}

In order to obtain multiple cracks during the four-point bending tests, mortar samples $\left(10 \times 40 \times 160 \mathrm{~mm}^{3}\right)$ containing PVA fibers (Kuraray) were produced (Table 5). Per batch $[\operatorname{REF}(\mathrm{m}), \mathrm{FA} 30(\mathrm{~m})$, FA50(m), S50(m) and S85(m)], six specimens were made. Details about the mix procedure can be found in Snoeck and De Belie (2012). The specimens were stored in a climate room at $20^{\circ} \mathrm{C}$ and more than $95 \%$ RH. After 1 day, the specimens were demoulded.

After 28 days of curing, the specimens were subjected to a displacement controlled four-point bending test (speed $0.005 \mathrm{~mm} / \mathrm{s}$ - maximum $5 \mathrm{~mm}$ deflection). Two to six cracks appeared per specimen. The initial width of these cracks was determined by optical microscopy (Leica S8APO and DFC295 camera) at different locations equally distributed along each crack.

\section{Measurement}

Each of the specimens was immersed in an alkaline solution/water and the healing capability was monitored (after 0, 1, 2, 7, 14, 21, and 64 or 69 days) by microscopic investigation. Therefore, samples were removed from the solution, wiped with a paper towel, and exposed to the air for some minutes. After the sample surfaces were dry, cracks were measured at the same locations as during the initial measurements.

Table 5. Mortar Composition of REF(m), FA30(m), FA50(m), S50(m), and $\mathrm{S} 85(\mathrm{~m})(\mathrm{g} /$ batch$)$ (with $\mathrm{m}=$ Multiple Cracks)

\begin{tabular}{lccccc}
\hline Component & REF $(\mathrm{m})$ & FA30 $(\mathrm{m})$ & FA50 $(\mathrm{m})$ & $\mathrm{S} 50(\mathrm{~m})$ & $\mathrm{S} 85(\mathrm{~m})$ \\
\hline OPC & $1,318.8$ & 923.2 & 659.4 & 659.4 & 197.8 \\
BFS & - & - & - & 659.4 & $1,121.0$ \\
FA & - & 395.6 & 659.4 & - & - \\
Water & 348.6 & 348.6 & 348.6 & 348.6 & 348.6 \\
Sand $(<200 \mu \mathrm{m})$ & 638.4 & 638.4 & 638.4 & 638.4 & 638.4 \\
Superplasticizer & 21.0 & 21.0 & 21.0 & 21.0 & 21.0 \\
PVA fibers & 36.4 & 36.4 & 36.4 & 36.4 & 36.4 \\
\hline
\end{tabular}




\section{Strength Regain}

The cracked and healed mortar prisms were reloaded after 6 (specimens subjected to three-point bending test) or 10 weeks (specimens subjected to four-point bending test). The strength regain was calculated according to Eq. (1)

$$
\text { Strength regain }=\frac{F_{2}}{F_{1}}
$$

with $F_{1}$ the peak load at the time the (first) crack occurs during the first loading cycle and $F_{2}$ the load at which the slope of the ascending curve changes during the reloading cycle. The authors refer to Fig. 1 for more clarification.

\section{Results}

\section{Calorimetry}

Figs. 2 and 3 show the isothermal heat production curves [in $\mathrm{J} /(\mathrm{g}$ crushed paste $) / \mathrm{h}]$ as a function of time. While Fig. 2 focuses on the effect of the different activators on a certain mix composition, Fig. 3 allows to evaluate the reactivity of a certain activator towards the different mix compositions. In Table 6, the cumulative heat production $(\mathrm{Q}$, calculated between $1 \mathrm{~h} 20 \mathrm{~min}$ and $160 \mathrm{~h}$ ) is summarized. The results clearly show that alkalis activate the pastes more than water [except for FA30(cp)]. The heat production rate and cumulative heat production is the lowest when the pastes are mixed with water. However, for reference mixes (containing only OPC as binder) and FA mixes, the difference with the alkaline activation is limited $\left(Q_{\text {alkali }} / Q_{\text {water }}<2.2\right)$. For mixes containing slag as binder, mixing with alkaline activators yields much higher reaction rates and total heat in comparison with mixing with water $\left(\mathrm{Q}_{\text {alkali }} / \mathrm{Q}_{\text {water }}\right.$ up to 4.5$)$ [except for the combination $\mathrm{S} 50(\mathrm{cp})$ $\mathrm{KOH}]$. The highest values of $\mathrm{Q}$ are obtained with Na-silicate and the $\mathrm{Ca}(\mathrm{OH})_{2}+\mathrm{Na}_{2} \mathrm{CO}_{3}$ solution. While it was expected that the $\mathrm{Ca}(\mathrm{OH})_{2}+\mathrm{Na}_{2} \mathrm{CO}_{3}$ solution would have about the same reactivity as the $1.75 \mathrm{M} \mathrm{NaOH}$ solution, since in the $\mathrm{Ca}(\mathrm{OH})_{2}+\mathrm{Na}_{2} \mathrm{CO}_{3}$ solution about $70 \%$ of the $\mathrm{Na}$ is transformed into $\mathrm{NaOH}$, this can only be recorded for the mixture $\mathrm{S} 50(\mathrm{cp})$ [and not for $\mathrm{S} 85(\mathrm{cp})$ ].

Fig. 3 clearly shows that for all the types of alkaline activators, pastes containing slag have the highest reaction rate. The reactivity of FA mixes is lower and these mixes even show a somewhat smaller heat flow than pure cement paste. The degree of reaction of the FA and BFS particles at the moment of testing was not

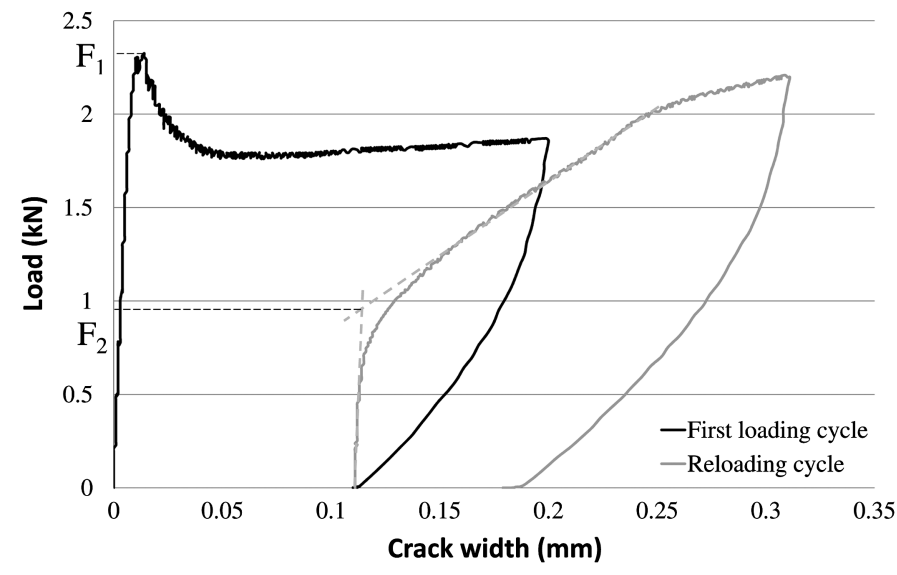

Fig. 1. Load curves during the first loading cycle and reloading cycle (example of a three-point bending test), with indication of F1 and F2 determined in this research. However, an estimate of the degree of reaction can be made based on the work performed by Baert (2009) and Gruyaert (2011), who respectively used FA and BFS delivered by the same supplier as the FA/BFS used in the current research. Baert investigated the degree of reaction of FA particles in mixes with $50 \%$ replacement of cement by FA and a water-tobinder ratio of 0.4 . The results showed that the degree of reaction was only a few percent after 28 days. Gruyaert (2011) showed that the degree of reaction of BFS particles in mixes with a water-tobinder of 0.5 and a BFS-to-binder ratio of 0.5 was about $37 \%$. These results clearly show that enough unreacted material is available that can be activated by alkalis for both types of mixes, but especially for the FA mixes. The difference in calorimetry between FA and BFS can thus not be explained by the degree of reaction of the FA/BFS particles at the moment of contact with the alkaline activator.

Although both FA and BFS can react with alkaline solutions via a so-called geo-polymerization reaction, the results presented here suggest that delayed activation of BFS by alkalis is more promising than that of FA (for self-healing concrete). However, the processes depend on the type of binder and alkaline activator and each different process has its own enthalpy change (heat production). With regard to self-healing, the occurrence of chemical reactions is not enough; also closure of the cracks and strength regain have to be investigated.

\section{Microscopy}

Microscopic investigation allows to evaluate the closure of cracks in mortar specimens submerged in different alkaline solutions. Fig. 4 shows an example [S85(cp) subjected to a $1.75 \mathrm{M} \mathrm{NaOH}$ solution] for which the cracks gradually close.

In order to compare the results of the different combinations binder-activator, the crack self-closing ratio $\beta$ as defined in Jaroenratanapirom and Sahamitmongkol (2011) was calculated in function of time [Eq. (2)]

$$
\beta(t)=1-\frac{A(t)}{A_{i}}
$$

with $A_{i}$ the area under the curve connecting the initial measuring points as in Fig. 5 and $A(t)$ the area under the curve connecting the measuring points obtained after $t$ days of crack healing as in Fig. 5. When cracks close, the value of $\beta$ approaches 1 .

Although the procedure of crack creation was the same for all specimens, cracks with different initial widths were obtained. In order to properly compare the results, $\beta$ values for different ranges of cracks were calculated $(0-125,125-250,250-375 \mu \mathrm{m})$.

\section{Closure of Cracks Created by Three-Point Bending Tests}

In Fig. 6, the self-closing ratio of cracks in the range of $0-125 \mu \mathrm{m}$ as a function of time is presented for the different mortar mixtures, which are exposed to water or alkaline solutions after cracking in three-point bending. The results show that the autogenous healing (submersion in water) capability of all mixtures is rather high. For the reference mix containing only OPC as binder, almost all cracks (with a width less than $125 \mu \mathrm{m}$ ) even close within the first 7 days. For the mixes containing supplementary cementitious materials, the values are somewhat lower, especially for the FA mixtures [up to $70 \%$ for FA30(s) and FA50(s) and up to $80-90 \%$ for S50(s) and S85(s) after 6 weeks]. The few results that are available for cracks in the range of 125-250 $\mu \mathrm{m}$ show that the larger the cracks, the slower the crack self-closing ratio approaches the value of 1 . Autogenous healing can be caused by different reasons [formation of calcium carbonate or calcium hydroxide, sedimentation of 

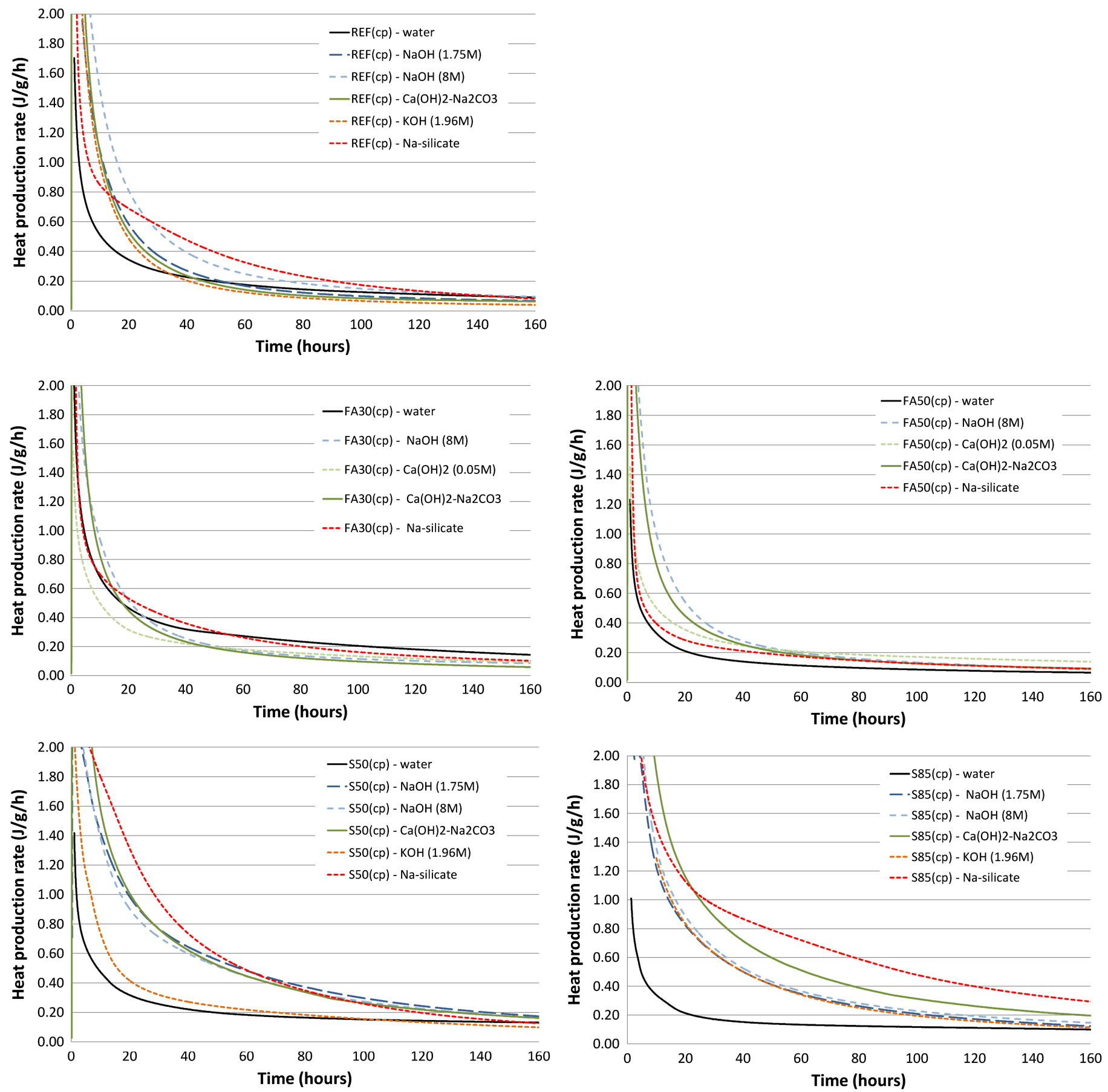

Fig. 2. Isothermal heat production curves $[$ in $\mathrm{J} / \mathrm{g}$ (crushed paste)/h] for the different mixtures

particles, continuing hydration or swelling of the cement matrix (ter Heide 2005)], but the most plausible explanation here is that mainly calcium carbonate is precipitated as white crystal deposits are noticed inside the crack and found by X-ray diffraction (XRD) and thermogravimetric (TG) analysis. This is caused by the fact that the specimens were subjected to wet-dry cycles (wet during submersion $\leftrightarrow$ dry during preparation for microscopic investigation and crack measurement). In that case, both water and $\mathrm{CO}_{2}$ are available, stimulating $\mathrm{CaCO}_{3}$ formation. If $\mathrm{CO}_{2}$ is missing, other mechanisms will get the upper hand. Here, the calorimetric measurements also indicate a limited reaction of unhydrated cement, FA or BFS. The fact that FA and BFS mixes do not perform as well as the OPC mixes can be explained when the main pathway of healing is considered. Since FA and BFS mixes do not contain as much $\mathrm{Ca}(\mathrm{OH})_{2}$ as reference mixes (Baert 2009; Gruyaert 2011), $\mathrm{CaCO}_{3}$ cannot be formed as easily as for reference mixes. Unhydrated particles are maybe available deeper inside the crack, but the effect of the formation of hydration products can be masked by the $\mathrm{CaCO}_{3}$ crystal precipitation, recorded by microscopic investigation at the crack face. For more information about autogenous healing in similar mixes, we refer to Van Tittelboom et al. (2012b).

While for the reference mixes healing in water gives the best results, crack healing in FA and BFS mixes can also be stimulated by submersion in alkaline solutions (results only for cracks $<125 \mu \mathrm{m}$ ). For FA50(s), the results of autogenous healing (submersion in water) are comparable with those of healing by alkaline 

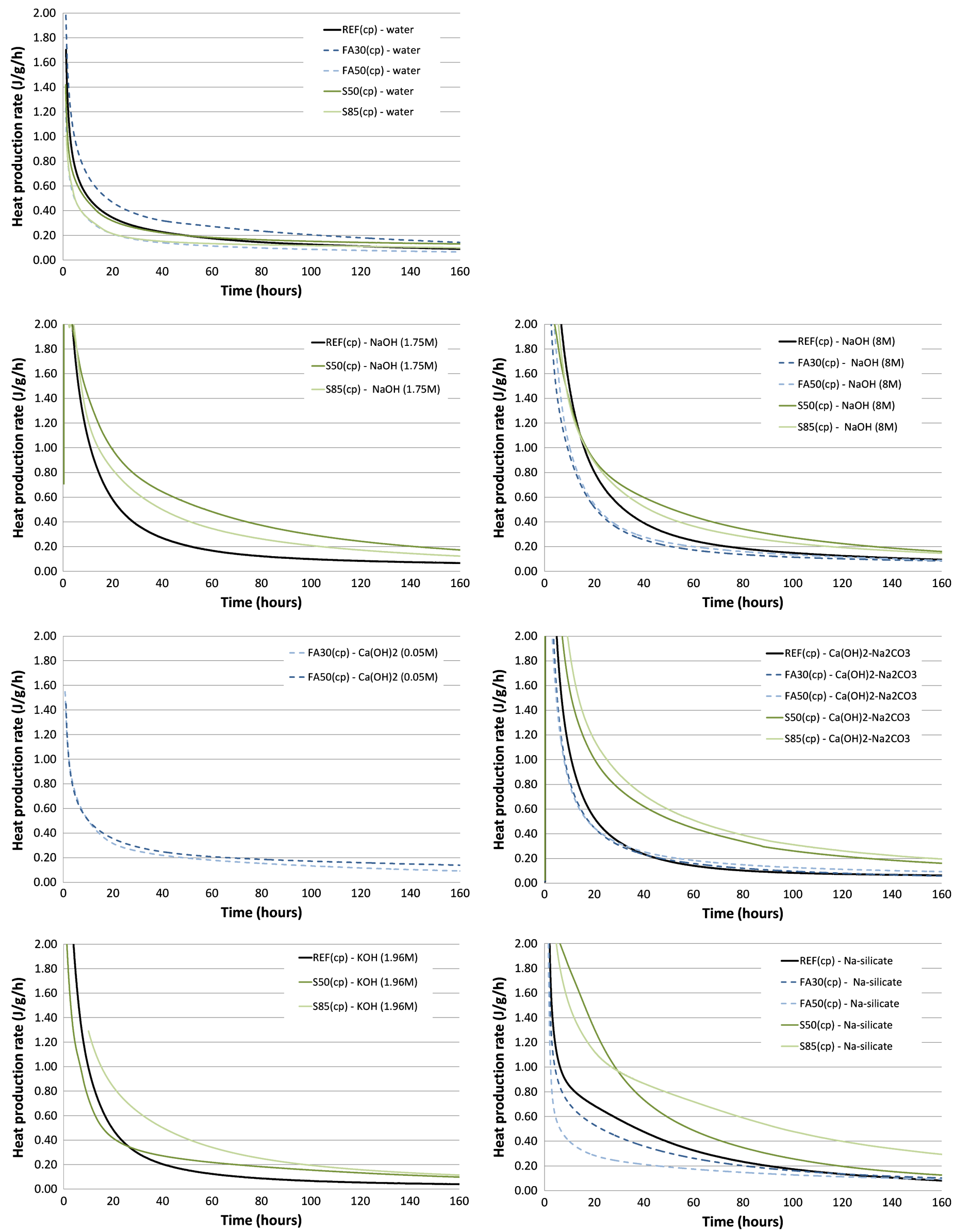

Fig. 3. Isothermal heat production curves $[$ in $\mathrm{J} / \mathrm{g}$ (crushed paste)/h] for the different alkaline activators 
Table 6. Cumulative Heat Production (J/g) (between 1 h 20 min and $160 \mathrm{~h}$ after Mixing)

\begin{tabular}{lccccr}
\hline Activator & $\begin{array}{c}\text { REF } \\
(\text { cp) }\end{array}$ & $\begin{array}{c}\text { FA30 } \\
\text { (cp) }\end{array}$ & $\begin{array}{c}\text { FA50 } \\
\text { (cp) }\end{array}$ & $\begin{array}{r}\text { S50 } \\
\text { (cp) }\end{array}$ & $\begin{array}{r}\text { S85 } \\
\text { (cp) }\end{array}$ \\
\hline Water & 33 & 42 & 21 & 34 & 25 \\
$\mathrm{NaOH}(1.75 \mathrm{M})$ & 44 & - & - & 83 & 66 \\
$\mathrm{NaOH}(8 \mathrm{M})$ & 64 & 43 & 48 & 78 & 72 \\
$\mathrm{Ca}(\mathrm{OH})_{2}(0.05 \mathrm{M})$ & - & 32 & 34 & - & - \\
$\mathrm{Ca}(\mathrm{OH})_{2}(1.25 \mathrm{M})+\mathrm{Na}_{2} \mathrm{CO}_{3}(1.25 \mathrm{M})$ & 45 & 40 & 30 & 88 & 99 \\
$\mathrm{KOH}(1.96 \mathrm{M})$ & 38 & - & - & 42 & 64 \\
$\mathrm{Na}_{2} \mathrm{O} \cdot 1.5 \mathrm{SiO}_{2} \cdot 13 \mathrm{H}_{2} \mathrm{O}$ & 55 & 46 & 30 & 90 & 112 \\
\hline
\end{tabular}

activation with an $8 \mathrm{M} \mathrm{NaOH}$ solution. For S50(s) and S85(s), submersion in a solution of $\mathrm{Ca}(\mathrm{OH})_{2}+\mathrm{Na}_{2} \mathrm{CO}_{3}$ gives even better results (complete closure of the cracks within $\sim 10$ days). The cracks in the S50(s) and S85(s) specimens also close for 90\% after submersion in a $1.75 \mathrm{M} \mathrm{NaOH}$ solution, but the rate is much slower in comparison to samples submerged in the $\mathrm{Ca}(\mathrm{OH})_{2}+\mathrm{Na}_{2} \mathrm{CO}_{3}$ solution (although both solutions contain about the same concentration of $\mathrm{NaOH}$ ). Moreover, visual inspection leads us to suspect that the reaction products are different (Fig. 7). With regard to the $1.96 \mathrm{M} \mathrm{KOH}$ solution, it can be noted that the crack self-closing ratio of $S 50(\mathrm{~s})$ and $S 85(\mathrm{~s})$ mixes evolves about the same as for the $1.75 \mathrm{M} \mathrm{NaOH}$ solution during the first 21 days (no further measurements are available for the $\mathrm{KOH}$ solution).

\section{Closure of Cracks Created by Four-Point Bending Tests}

In Fig. 8, the crack self-closing ratio as a function of time is presented for the different mortar mixtures, which are exposed to water or alkaline solutions after cracking in four-point bending. While most of the cracks created by three-point bending tests are smaller than $125 \mu \mathrm{m}$, now also cracks up to $250 \mu \mathrm{m}$ and even $375 \mu \mathrm{m}$ are available for evaluation.
While the cracks created in the mortar specimens by means of three-point bending tests show a high autogenous healing efficiency, the performance is much less for the cracks created in the mortar specimens by means of four-point bending tests. A possible explanation can be that the specimens with PVA fiber reinforcement should have been handled with more caution since the stiffness of these specimens is lower than those with steel reinforcement used for the three-point bending test (possible crack healing material could have been damaged during manipulation of the specimens). Again, it can be noticed that the wider the cracks, the slower the healing occurs.

With regard to the alkaline solutions, the crack self-closing ratio of the reference (OPC) mixtures is limited and varies generally between 15 and $30 \%$ after 10 weeks of submersion. No considerable difference can be found between the different alkaline activators under examination.

For the FA mixes, healing efficiencies up to $30 \%$ are recorded for the different alkalis tested. Since none of them performs very well, it is difficult to select the most suitable activator for FA mixes. Moreover, the comment mentioned earlier about the manipulation of the specimens must be taken into account.

Similar to the results already presented, the most suitable activator for slag mortars seems to be a solution of $\mathrm{Ca}(\mathrm{OH})_{2}+\mathrm{NaCO}_{3}$. Especially for the $\mathrm{S} 85(\mathrm{~m}) \mathrm{mix}$, a very high crack self-closing ratio is obtained after 10 weeks $(>90 \%)$. For the mix S50(m), the ratio is lower but is still the highest of all tested alkaline solutions. Unfortunately, the specimens submersed in a $\mathrm{Ca}(\mathrm{OH})_{2}+\mathrm{NaCO}_{3}$ solution do not contain cracks with a width higher than $125 \mu \mathrm{m}$. As a consequence, the healing capacity of a $\mathrm{Ca}(\mathrm{OH})_{2}+\mathrm{Na}_{2} \mathrm{CO}_{3}$ solution towards larger cracks cannot be evaluated. The performance of $\mathrm{S} 50(\mathrm{~m})$ and $\mathrm{S} 85(\mathrm{~m})$ in combination with the other types of activators is small (maximum $40 \%$ for cracks widths $<125 \mu \mathrm{m}$ ) and decreases with increasing crack width (up to $30 \%$ for crack widths between 125 and $250 \mu \mathrm{m}$ and up to $20 \%$ for crack widths between
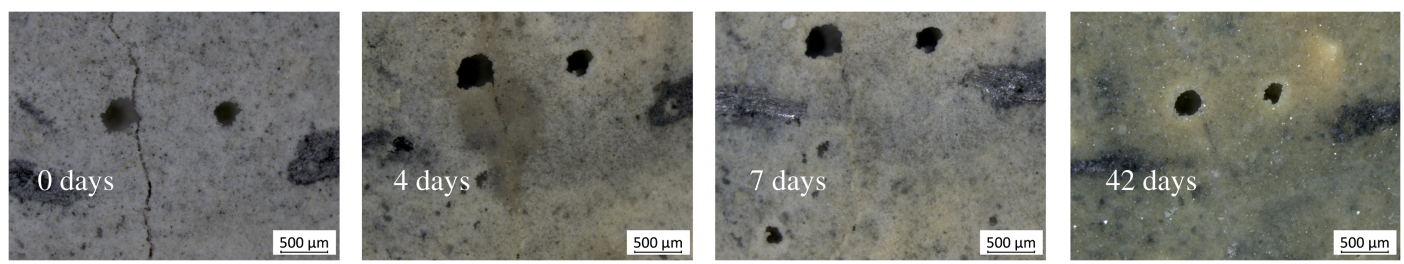

Fig. 4. Visualization of crack closure by means of optical microscopy [example: S85(s)-NaOH (1.75M)]
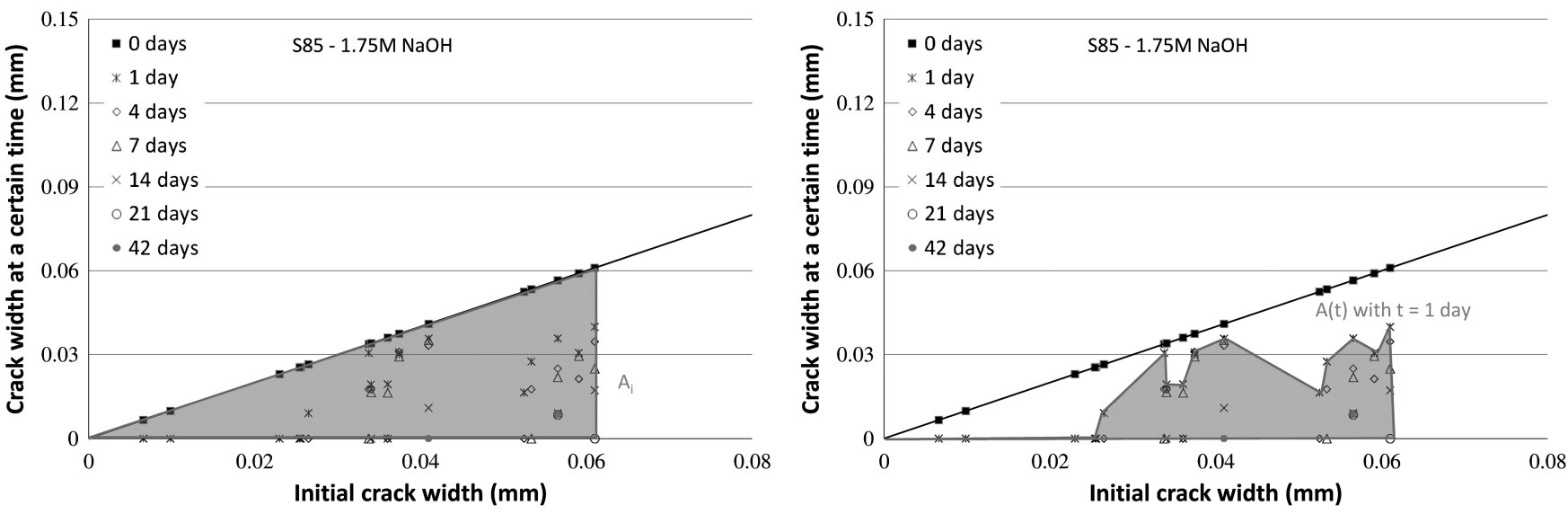

Fig. 5. Calculation method of the crack self-closing ratio 

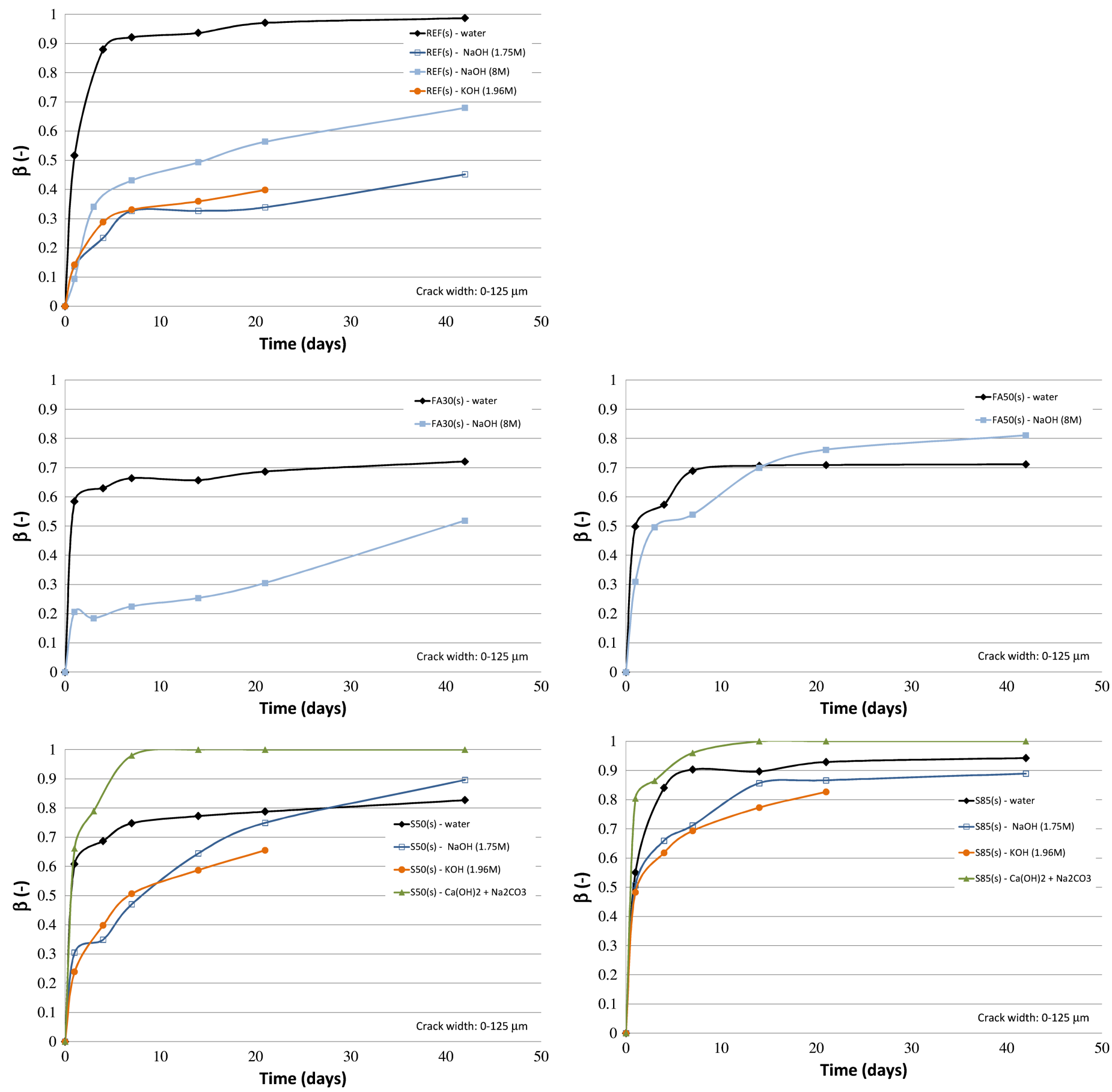

Fig. 6. Crack self-closing ratio in function of time for cracks created by three-point bending tests; the lines are flowing lines connecting the measuring points
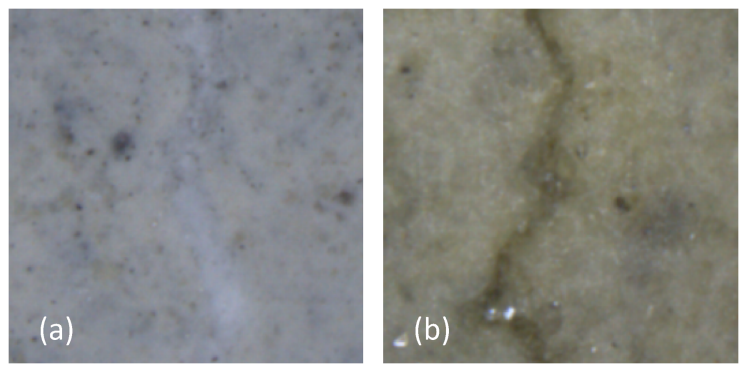

Fig. 7. Visualization of crack closure by means of optical microscopy: (a) $\mathrm{S} 50$ (s) after 21 days in a $\mathrm{Ca}(\mathrm{OH})_{2}+\mathrm{Na}_{2} \mathrm{CO}_{3}$ solution; (b) $\mathrm{S} 50$ (s) after 21 days in a $1.75 \mathrm{M} \mathrm{NaOH}$ solution
250 and $375 \mu \mathrm{m})$. Again, the influence of activation by $\mathrm{NaOH}$ $(1.75 \mathrm{M})$ and $\mathrm{KOH}(1.96 \mathrm{M})$ is quite similar.

\section{Strength Regain}

In Tables 7 and 8, the regain in strength due to crack healing is presented. As can be seen, the strength regain (generally between 10 and 40\%) is limited in comparison with other self-healing techniques [e.g., Van Tittelboom (2012a) obtained values up to $80 \%$ for self-healing with polymeric healing agents (polyurethane)].

For the three-point bending tests (Table 7), three specimens per batch were tested. A one-way ANOVA test and Student-NewmanKeuls (equal variances) or Dunnett's T3 (no equal variances) post hoc test was executed. In advance, the homogeneity of the 

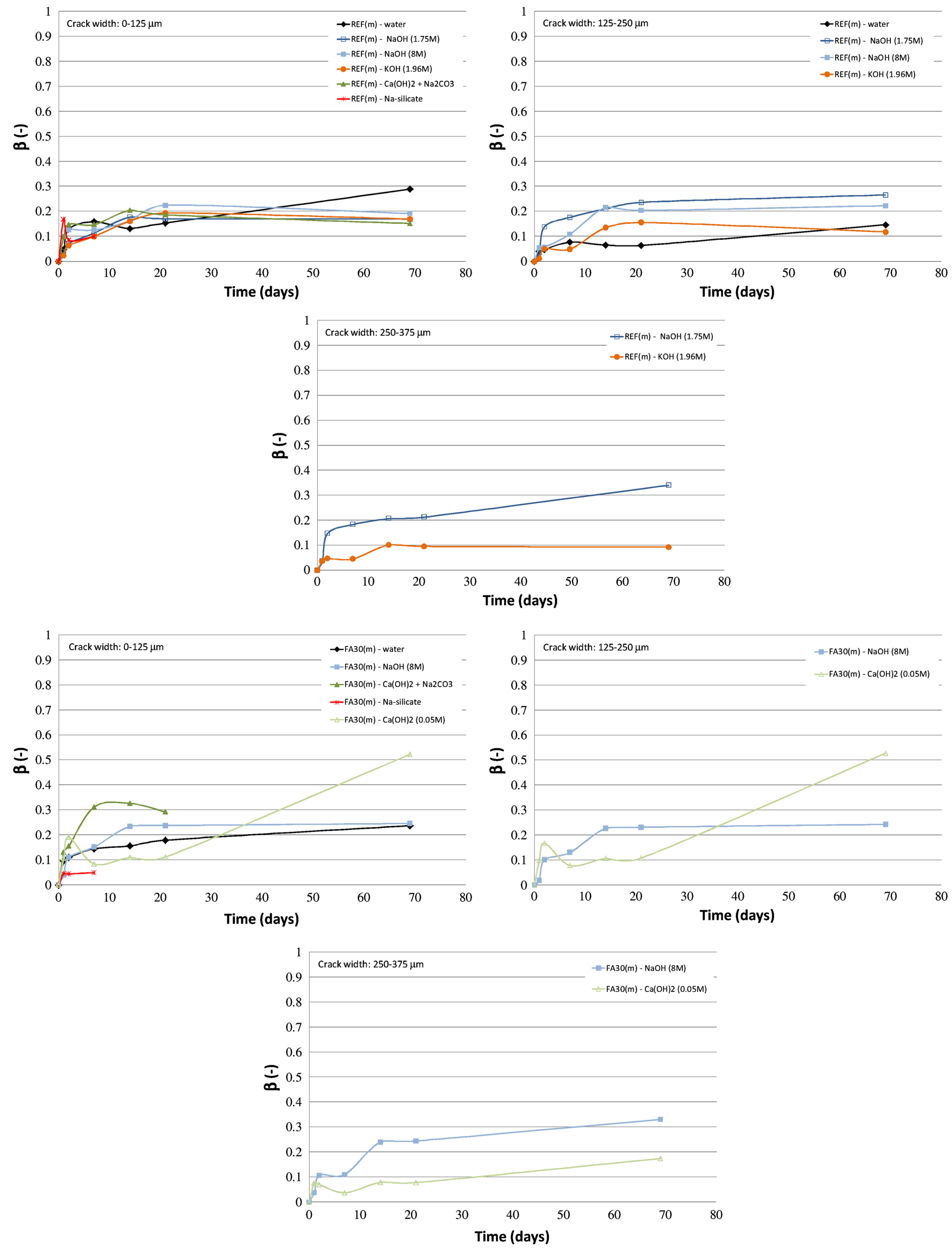

Fig. 8. Crack self-closing ratio in function of time for cracks created by four-point bending tests; the lines are flowing lines connecting the measuring points 

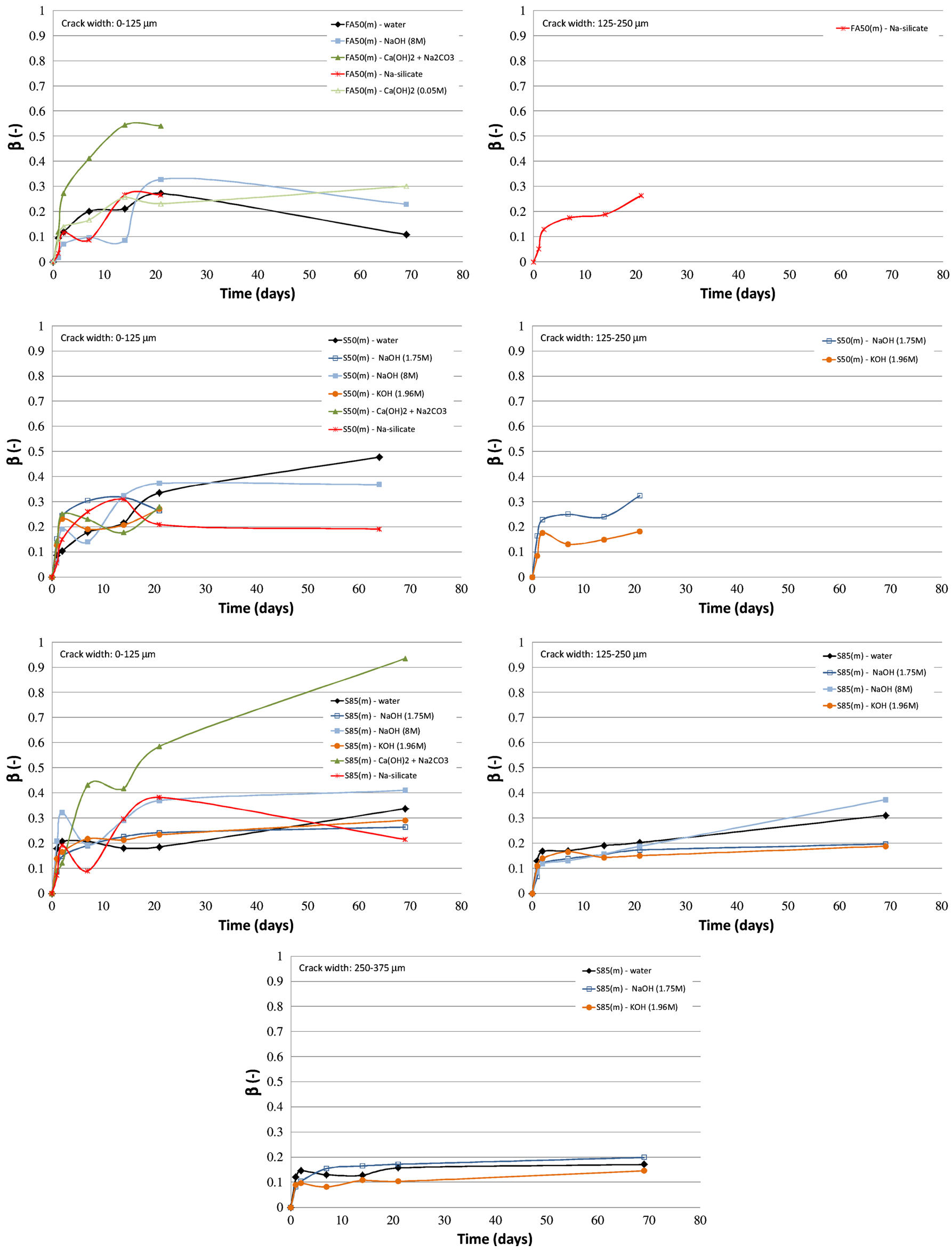

Fig. 8. (Continued.) 
Table 7. Strength Regain after Crack Repair (\%) (Three-Point Bending Tests) (Mean Value and Standard Error in between Brackets)

\begin{tabular}{lccccc}
\hline Activator & REF & FA30 & FA50 & S50 & S85 \\
\hline Water & $19(7.3)$ & $12(1.9)$ & $12(0.4)$ & $20(3.7)$ & $34(12.7)$ \\
$\mathrm{NaOH}(1.75 \mathrm{M})$ & $10(3.8)$ & - & - & $24(2.3)$ & $34(4.7)$ \\
$\mathrm{NaOH}(8 \mathrm{M})$ & $11(4.2)$ & $21(3.0)$ & $28(3.0)$ & - & - \\
$\mathrm{Ca}(\mathrm{OH})_{2}$ & - & $19(3.0)$ & $29(1.6)$ & - & - \\
$\mathrm{Ca}(\mathrm{OH})_{2}(1.25 \mathrm{M})$ & - & - & - & $29(2.5)$ & $30(4.3)$ \\
$+\mathrm{Na}_{2} \mathrm{CO}_{3}(1.25 \mathrm{M})^{\mathrm{a}}$ & & & & & \\
$\mathrm{KOH}(1.96 \mathrm{M})$ & $24(1.8)$ & - & - & $22(2.7)$ & $45(4.5)$ \\
\hline
\end{tabular}

${ }^{\mathrm{a}} 92.5 \mathrm{~g} \mathrm{Ca}(\mathrm{OH})_{2}+132.5 \mathrm{~g} \mathrm{Na}_{2} \mathrm{CO}_{3}+1 \mathrm{~L}$ water; in the case of the $\mathrm{Ca}(\mathrm{OH})_{2} / \mathrm{Na}_{2} \mathrm{CO}_{3}$ activator, the dry components were added to the cement powder before addition of water.

Table 8. Strength Regain after Crack Repair (\%) (Four-Point Bending Tests)

\begin{tabular}{lcccrr}
\hline Activator & REF & FA30 & FA50 & S50 & S85 \\
\hline Water & 19 & 41 & 60 & 26 & 18 \\
$\mathrm{NaOH}(1.75 \mathrm{M})$ & - & - & - & 4 & 7 \\
$\mathrm{NaOH}(8 \mathrm{M})$ & 5 & - & - & - & 31 \\
$\mathrm{Ca}(\mathrm{OH})_{2}(0.05 \mathrm{M})$ & - & 7 & 17 & - & - \\
$\mathrm{Ca}(\mathrm{OH})_{2}(1.25 \mathrm{M})+\mathrm{Na}_{2} \mathrm{CO}_{3}(1.25 \mathrm{M})^{\mathrm{a}}$ & 25 & 13 & 50 & 43 & 71 \\
$\mathrm{KOH}(1.96 \mathrm{M})$ & 43 & - & - & 10 & 37 \\
$\mathrm{Na}_{2} \mathrm{O} \cdot 1.5 \mathrm{SiO}_{2} \cdot 13 \mathrm{H}_{2} \mathrm{O}$ & 0 & 23 & 0 & 0 & 0 \\
\hline
\end{tabular}

${ }^{\mathrm{a}} 92.5 \mathrm{~g} \mathrm{Ca}(\mathrm{OH})_{2}+132.5 \mathrm{~g} \mathrm{Na}_{2} \mathrm{CO}_{3}+1 \mathrm{~L}$ water; in the case of the $\mathrm{Ca}(\mathrm{OH})_{2} / \mathrm{Na}_{2} \mathrm{CO}_{3}$ activator, the dry components were added to the cement powder before addition of water.

variances was checked with a Levene's test (two tails and level of significance $=0.05)$. The results clearly show that for $\operatorname{REF}(\mathrm{s})$, FA30(s), S50(s), and S85(s), the strength regain does not depend on the type of alkaline activator used (no significant differences found). Only for FA50(s), the strength regain obtained after submersion in alkaline activators $\left[\mathrm{Ca}(\mathrm{OH})_{2}(0.05 \mathrm{M})\right.$ or $\left.\mathrm{NaOH}(8 \mathrm{M})\right]$ is significantly different from that obtained after autogenous healing. Considering the different activators, the following can be concluded: (1) the strength regain after healing is about the same for all types of mortars; (2) the mixtures with slag [S50(s) and S85(s)] have a significant higher strength regain after submersion in a $1.75 \mathrm{M} \mathrm{NaOH}$ solution compared to the reference mix in the same solution; (3) for the $8 \mathrm{M} \mathrm{NaOH}$ solution, the strength regain of FA50(s) is significantly higher compared to that of REF(s) [strength regain of FA30(s) does not significantly differ from REF(s) and FA50(s)]; and (4) healing by immersion in $\mathrm{KOH}(1.96 \mathrm{M})$ yields the highest strength regain for S85(s) [REF(s) and S50(s) significantly different from S85(s)].

With regard to the four-point bending tests (Table 8), no statistical analyses could be performed since only one test result was available per tested combination. This makes it difficult to draw conclusions. The results obtained from the four-point bending tests do not always correspond well with the results obtained from the three-point bending tests. Nevertheless, it seems that (1) strength regain after submersion in a Na-silicate solution is almost nil; (2) for $\mathrm{NaOH}(1.75 \mathrm{M})$ and $\mathrm{Ca}(\mathrm{OH})_{2}$ solutions, the regain in mechanical properties is limited; and (3) healing by submersion in $\mathrm{Ca}(\mathrm{OH})_{2}+$ $\mathrm{Na}_{2} \mathrm{CO}_{3}$ solutions yields a moderately to high regain in strength.

\section{Conclusions}

This paper presents a preliminary study performed in order to evaluate the use of alkaline activators for crack repair of FA and BFS concrete. The cement replacement percentages are
30 and $50 \%$ for $\mathrm{FA}$ and 50 and $85 \%$ for BFS. The tested alkaline activators are $\mathrm{NaOH}(1.75 \mathrm{M}$ and $8 \mathrm{M}), \mathrm{KOH}(1.96 \mathrm{M})$, $\mathrm{Ca}(\mathrm{OH})_{2}(0.05 \mathrm{M}), \mathrm{Ca}(\mathrm{OH})_{2}(1.25 \mathrm{M})+\mathrm{Na}_{2} \mathrm{CO}_{3}(1.25 \mathrm{M})$, and $\mathrm{Na}_{2} \mathrm{O} \cdot 1.5 \mathrm{SiO}_{2} \cdot 13 \mathrm{H}_{2} \mathrm{O}$. For comparison, the autogenous healing capacity is also determined.

With regard to autogenous healing, it could be concluded from the calorimetric measurements that alkalis activate pastes more than water. Nevertheless, the crack self-closing ratio of specimens subjected to wet-dry cycles in water was very high and cracks were healed in an autogenous way within a time span of less than 10 days, especially for the OPC mixes. The autogenous healing capacity of FA and BFS mixes was somewhat lower as due to wetting and drying during the microscopic measurements the main mechanism of crack healing was the precipitation of $\mathrm{CaCO}_{3}$. The strength regain obtained when samples were submerged in water was rather limited and amounted to $10-30 \%$.

With regard to autonomous healing by alkaline activation, calorimetric measurements gave a first indication with regard to the suitable activators and showed that BFS concrete probably has more potential to be reactivated by alkalis than FA concrete. Taking into account the other test results (evolution of crack closure and strength regain), also the most suitable activator for BFS concrete could be selected. In a solution of $\mathrm{Ca}(\mathrm{OH})_{2}+\mathrm{Na}_{2} \mathrm{CO}_{3}$, the cracks in mortar samples with BFS closed completely within a reasonable time span, but strength regain was still limited (30-70\%). Although good results were obtained for this combination, it is not sure whether wider cracks $(>125 \mu \mathrm{m})$ can also be healed. Moreover, for the other combinations tested (slag/fly ash and alkaline solution), the results were not satisfying enough to elaborate the original idea to encapsulate alkaline activators in concrete.

\section{Acknowledgments}

This research under the program SHE (Engineered Self-Healing materials) (project SECEMIN: Self-healing CEmentitious and MINeral building materials) was funded by SIM (Strategic Initiative Materials) in Flanders. The authors would like to thank the foundation for their financial support. The authors thank Brenda Debbaut for her help with data processing.

\section{References}

Arjunan, P., Silsbee, M. R., and Roy, D. M. (2001). "Chemical activation of low calcium fly ash. Part 1: Identification of suitable activators and their dosage." Int. Ash Utilization Symp., KY.

Baert, G. (2009). "Physico-chemical interactions in portland cement(High volume) fly ash binders." Ph.D. dissertation, Ghent Univ., Ghent, Belgium.

Bernal, S. A., Mejia de Gutierrez, R., Pedraza, A. L., Provis, J. L., Rodriguez, E. D., and Delvasto, S. (2011). "Effect of binder content on the performance of alkali-activated slag concretes." Cem. Concr. Res., 41(1), 1-8.

Buchwald, A., Vanooteghem, M., Gruyaert, E., Hilbig, H., and De Belie, N. (2013). "Purdocement: Application of alkali-activated slag cement in Belgium in the 1950s." Mater. Struct.

Dennis Lee, H. X., Wong, H. S., and Buenfeld, N. (2010). "Self-sealing cement-based materials using superabsorbent polymers." Int. RILEM Conf. on Use of Superabsorbent Polymers and Other New Additives in Concrete, O. M. Jensen, M. Hasholt, T. Laustsen, and S. Lyngby, eds., RILEM Publications, Bagneux, France, 171-178.

Deschner, F., et al. (2013). "Quantification of fly ash in hydrated, blended portland cement pastes by back-scattered electron imaging." J. Microsc., 251(2), 188-204. 
Dry, C., and McMillan, W. (1996). "Three-part methylmethacrylate adhesive system as an internal delivery system for smart responsive concrete." Smart Mater. Struct., 5(3), 297-300.

Gruyaert, E. (2011). "Effect of blast-furnace slag as cement replacement on hydration, microstructure, strength and durability of concrete." Ph.D. dissertation, Ghent Univ., Ghent, Belgium.

Gruyaert, E., Robeyst, N., and De Belie, N. (2010). "Study of the hydration of portland cement blended with blast-furnace slag by calorimetry and thermogravimetry." J. Therm. Anal. Calorim., 102(3), 941-951.

Jaroenratanapirom, D., and Sahamitmongkol, R. (2011). "Self-crack closing ability of mortar with different additives." J. Metals Mater. Miner., 21(1), 9-17.

Kim, J. S., and Schlangen, E. (2010). "Super absorbent polymers to stimulate self healing in ECC." 2nd Int. Symp. on Service Life Design for Infrastructure, RILEM Publications, Bagneux, France.

Kocaba, V., Gallucci, E., and Scrivener, K. (2012). "Methods for determination of degree of reaction of slag in blended cement pastes." Cem. Concr. Res., 42(3), 511-525.

Lumley, J. S., Gollop, R. S., Moir, G. K., and Taylor, H. F. W. (1996). "Degrees of reaction of the slag in some blends with portland cements." Cem. Concr. Res., 26(1), 139-151.

NBN. (2005). "Methods of testing cement-Part 1: Determination of strength." EN 196-1, Brussels, Belgium.

NBN. (2011). "Cement-Composition, specifications and conformity criteria for common cements." EN 197-1, Brussels, Belgium.

Provis, J., and van Deventer, J., eds. (2014). Alkali activated materials, state-of-the-art report TC 224-AAM, Springer, Dordrecht, Netherlands.

Purdon, A. O. (1940). "The action of alkalis on blast-furnace slag." J. Soc. Chem. Ind.: Trans. Commun., 59, 191-202.

Shi, C., Krivenko, P. V., and Roy, D. (2006). Alkali-activated cements and concretes, Taylor and Francis, Abingdon, U.K.
Snoeck, D., and De Belie, N. (2012). "Mechanical and self-healing properties of cementitious composites reinforced with flax and cottonised flax, and compared with polyvinyl alcohol fibres." Biosyst. Eng., 111(4), $325-335$.

Snoeck, D., Van Tittelboom, K., Steuperaert, S., Dubruel, P., and De Belie, N. (2013). "Self-healing cementitious materials by the combination of microfibers and superabsorbent polymers." J. Intell. Mater. Syst. Struct., 25(1), 13-24.

ter Heide, N. (2005). "Crack healing in hydrating concrete." M.Sc. thesis, Delft Univ. of Technology, Delft, Netherlands.

Thao, T. D. P., Johnson, T., Tong, Q., and Dai, P. (2009). "Implementation of self-healing in concrete-Proof of concept." IES J. Part A: Civ. Struct. Eng., 2(2), 116-125.

Van Tittelboom, K., De Belie, N., De Muynck, W., and Verstraete, W. (2010). "Use of bacteria to repair cracks in concrete." Cem. Concr. Res., 40(1), 157-166.

Van Tittelboom, K., De Belie, N., Lehmann, F., and Grosse, C. U. (2012a). "Acoustic emission analysis for the quantification of autonomous crack healing in concrete." Constr. Build. Mater., 26(1), 532-540.

Van Tittelboom, K., De Belie, N., Van Loo, D., and Jacobs, P. (2011). "Selfhealing efficiency of cementitious materials containing tubular capsules filled with healing agent." Cem. Concr. Compos., 33(4), 497-505.

Van Tittelboom, K., Gruyaert, E., and De Belie, N. (2012b). "Influence of mix composition on the autogenous crack healing efficiency." Constr. Build. Mater., 37, 349-359.

Wang, J., Van Tittelboom, K., De Belie, N., and Verstraete, W. (2012). "Use of silica gel or polyurethane immobilized bacteria for self-healing concrete." Constr. Build. Mater., 26(1), 532-540.

Wiktor, V., and Jonkers, H. M. (2011). "Quantification of crack-healing in novel bacteria-based self-healing concrete." Cem. Concr. Compos., 33(7), 763-770. 